\title{
Potential of the compact extended aeration reactor (CEAR) as an integrated system to biologically degrade municipal sewage according to Malaysian regulatory limits: design, process and performance
}

\author{
S. R. M. Kutty, M. H. Isa, A. Nasiru, I. U. Salihi \& H. Ezerie \\ Civil Engineering Department, Universiti Teknologi PETRONAS, \\ Malaysia
}

\begin{abstract}
A laboratory scale integrated biological reactor was designed and fabricated to perform organic removal, nitrification and denitrification from synthetic sewage with the C:N:P ratio 100:10:2. The configuration of the reactor is anoxic-aeration and anoxic with a settler, integrated within one system. A suspended growth medium guarantees adequate organic and nutrient removal, in a continuous flow stirred chamber reactor (CFSTR). The arrangement resembles the Bardenpho process, which combines Wuhrmann's and modified Ludzak-Ettinger processes. The purpose is innovation to provide a minimal footprint to make the system modular, user friendly, with easy operation and maintenance compared with conventional methods. Similarly, the aim is to attain the Department of Environment (DOE) Malaysia revised Environment Quality Regulation Act 2009 (EQA, 1974) review on ammonia, nitrate and phosphorus discharge limits by reducing negative impacts due to discharge into receiving water bodies. Effluent ammonia and nitrate limits were set at a minimum of $5 \mathrm{mg} / \mathrm{L}$ and $10 \mathrm{mg} / \mathrm{L}$, respectively. The removal of phosphorus was inadequate because phosphorus requires an anaerobic process. The reduction of biochemical oxygen demand (BOD5), chemical oxygen demand (COD), ammonia-nitrogen (NH4-N), nitratenitrogen (NO3-N), total phosphorus (TP) and total suspended solids (TSS) were achieved at $92.8 \%, 89.5 \%, 81 \%, 66 \%, 23 \%$ and $92.5 \%$, respectively. The removal of ammonia and nitrate-nitrogen were enhanced within the last phase at $90.2 \%$ and $80 \%$ reduction, respectively.
\end{abstract}

Keywords: integrated biological reactor, organic removal, nitrificaction, dentrification, extended aeration, footprint. 


\section{Introduction}

Towards advocacy for environmentally sound and sustainable development, the Department of Environment (D.O.E.) Malaysia in 2009 reviewed and included additional requirements in the environmental regulations for domestic and industrial effluent discharge (DOE [1]). Among those changes is the implementation of Environmental Quality (Sewage) Regulations 2009, which has expressively reduced the discharge limit of ammonia-nitrogen from $50 \mathrm{mg} / \mathrm{L}$ to 5 $\mathrm{mg} / \mathrm{L}$. Subsequently, a new discharge limit for nitrate was also set at $10 \mathrm{mg} / \mathrm{L}$ (Kutty et al. [2]). Therefore, these downward reviews oblige the need for improved wastewater treatment system that is efficient in removing these harmful nutrients that are potential hazard to human health and the environment.

There is increased recognition by environmental protection professionals on the adverse impacts that can be caused by incessant discharge of nutrients, especially nitrogen and phosphorus into the aquatic environment (Howarth et al. [3]). Improved prominence on the control for nutrients has resulted in the development of emerging wastewater innovations, which include biological nutrient removal (BNR) processes. Some of these removal processes use suspended growth, while others use fixed film (Sedlak [4]).

Activated sludge process (ASP) is proven as versatile biological process adopted generally for the secondary treatment of domestic, municipal and industrial wastewater (Hait and Mazumder [5]). Currently, several modifications of the ASP have been made to improve the degree of treatment in accordance with stringent effluent standards set by various regulatory establishments (Hait and Mazumder [5]). Conventional activated-sludge (CAS) processes employed in the current domestic sewage treatment plants in Malaysia are seldom capable of attaining the new regulations, as nitrification is inhibited due to insufficient solids retention time (SRT) and sludge age of the biomass (Kutty et al. [2]). SRT influences the performance of activated sludge treatment process, aeration chamber volume, sludge production, and oxygen requirements (Kutty et al. [6]). Extended aeration system is confirmed to be more viable than conventional system in terme of nitrogen removal efficiency (Kutty et al. [6]).

Rapid growth of the human population and industrialization has amplified the environmental problems such as water, air and land pollution as well as competition for land (Baron et al. [7]). Major step in Malaysia's wastewater management was initiated in 1974 when the government established the Environmental Quality Act which was the first national legal framework for regulating the quality of effluent water from sewage and industries (Ujang and Henze [8]). In 1980 the Malaysian parliament effected a new law mandating developers of new housing development comprising more than 30 houses to provide proper sewage treatment systems (SSD [9]). Therefore developers need to allocate some area of land to build a wastewater treatment plant (WWTP) in order to abide by the directives given. As a proposed development area is increased, the population equivalent is increased and so does the WWTP area to be made (Chiplunkar and Seetharam [10]). The high usage of land for WWTP may be costly to developers where they can use the land for other purpose which brings 
them more income. As a result of these challenges, an idea to have an integrated wastewater treatment system where the processes of wastewater treatment are combined into a single reactor is derived.

Impacts of nutrients on the aquatic environment include ammonia-nitrogen exerting oxygen demand due to oxidation in the aquatic environment, depleting dissolved oxygen (Salama et al. [11]). This is in addition to aquatic toxicity, resulting from unionized ammonia-nitrogen being toxic to a variety of aquatic organisms including fish (Keng et al. [12]), nitrate-nitrogen on water supply as well as causing methemoglobinemia (blue baby syndrome) in potable water (Daigger and Lim [13]). Total-nitrogen causes eutrophication which impacts on excessive growths of aquatic organisms that deplete dissolved oxygen and excrete organic compounds that cause taste and odor (Daigger and Lim [13]). Serious health concerns prompted better designs and planning of wastewater monitoring (Carroll [14]).

There are two discharge criteria for effluent wastewater in Malaysia, namely standards A and B; standard A is applicable to discharges into any inland waters within catchment areas listed in the third Schedule, while standard B is applicable to any other inland waters or Malaysian waters. Consequently, standard A is when the water uptake (for drinking purposes) is downstream and Standard B is when water uptake is upstream (DOE [1]). The ultimate aim of this research is to ensure to provide proof of concept for the integrated wastewater facility which is capable of removing organics and nutrients.

\subsection{Process description of organic removal and biochemistry}

Aerobic biological decomposition of an organic waste will continue until all the waste is degraded with sufficient oxygen, while three essential distinct activities occur in the aeration chamber. Portion of the waste is oxidized to an end-product to obtain energy for cell maintenance followed by synthesis of new cell tissue . Concurrently, some of the waste is converted into new cell tissue using part of the energy released during oxidation. Finally, when organic matter is used up, the new cell begins to consume own cell tissue to obtain energy for cell maintenance. The last process is called endogenous respiration [15]. Using term CHONS to represent Carbon, Oxygen, Hydrogen, Nitrogen, and Sulphur to signify organic matter in wastewater and the term $\mathrm{C}_{5} \mathrm{H}_{7} \mathrm{NO}_{2}$ [15] to denote cell tissue. Three equations illustrate the generalized chemical reactions of aerobic oxidation as shown below:

Oxidation:

CHONS (organic matter) $+\mathrm{O}_{2}+$ bacteria $\rightarrow \mathrm{CO}_{2}+\mathrm{H}_{2} \mathrm{O}+\mathrm{NH}_{3}$

Synthesis:

$$
\mathrm{CHONS}+\mathrm{O}_{2}+\text { bacteria }+ \text { energy } \rightarrow \mathrm{C}_{5} \mathrm{H}_{7} \mathrm{NO}_{2} \text { (new cell) }
$$

Endogenous Respiration:

$$
\mathrm{C}_{5} \mathrm{H}_{7} \mathrm{NO}_{2}+5 \mathrm{O}_{2} \rightarrow 5 \mathrm{CO}_{2}+\mathrm{NH}_{3}+2 \mathrm{H}_{2} \mathrm{O}
$$




\subsection{Nitrification}

Nitrification is the autotrophic oxidation of $\mathrm{NH}_{4}{ }^{+}-\mathrm{N}$, first to $\mathrm{NO}_{2}-\mathrm{N}$ and then, to $\mathrm{NO}_{3}-\mathrm{N}$. The two-steps reaction is usually very rapid and hence it is rare to find $\mathrm{NO}_{2}$ - levels above $1.0 \mathrm{mg} / \mathrm{L}$ in wastewater [15]. The bacteria, known as "nitrifiers," are strict aerobes, implying that presence of free dissolved oxygen is imperative in order for them to perform well. Nitrification can only occur under aerobic condition at dissolved oxygen (DO) levels of $2.0 \mathrm{mg} / \mathrm{L}$ or higher [15]. Nitrification requires long detention time, since nitrifiers grow very slowly, low food to microorganism ratio (F:M), a high mean cell residence time (measured as MCRT or Sludge Age), and adequate buffering alkalinity [15]. Nitrification process requires optimum temperature between 30 to $35^{\circ} \mathrm{C}$ in order to successfully accomplish a treatment [16]. Another important factor during nitrification process is the $\mathrm{pH}$ level, and rates decline below $\mathrm{pH}$ value of 6.8 [15]. However, most wastewater treatment plants are able to effectively nitrify with a $\mathrm{pH}$ of 7.0 to 7.2. Chemical oxidation of ammonia during nitrification are as shown in eqn 4 and eqn 5 , while overall conversion is in eqn 7 [15]. Conversion of ammonium ions to nitrite as characterized by Nitrosomonas is given as:

$$
\mathrm{NH}_{4}^{+}+1.5 \mathrm{O}_{2} \rightarrow 2 \mathrm{H}^{+}+2 \mathrm{H}_{2} \mathrm{O}+\mathrm{NO}_{2}^{-}
$$

Conversion of nitrite ions to nitrate ions (as typified by Nitrobacter):

$$
\mathrm{NO}_{2-}+0.5 \mathrm{O}_{2} \rightarrow \mathrm{NO}_{3}^{-}
$$

Overall process:

$$
\mathrm{NH}_{4}^{+}+2 \mathrm{O}_{2} \rightarrow 2 \mathrm{H}^{+}+\mathrm{H}_{2} \mathrm{O}+\mathrm{NO}_{3}^{-}
$$

$$
\mathrm{NH}_{4}{ }^{+}+1.856 \mathrm{O}_{2}+1.98 \mathrm{HCO}_{3}{ }^{-} \rightarrow 0.021 \mathrm{C}_{5} \mathrm{H}_{7} \mathrm{O}_{2} \mathrm{~N}+0.98 \mathrm{NO}_{3}{ }^{-}+2.92 \mathrm{H}_{2} \mathrm{O}+
$$

From eqn (7), every pound of ammonia oxidized to nitrate, 4.18 of oxygen are consumed (required) and 7.14 of alkalinity are consumed (required), measured as calcium carbonate $\left(\mathrm{CaCO}_{3}^{-}\right)$or $12 \mathrm{~kg}$ of alkalinity measured as sodium bicarbonate $\left(\mathrm{NaHCO}_{3}\right)$.

\subsection{Denitrification}

Denitrification is the reduction process of nitrate to nitric oxide, nitrous oxide and nitrogen gas by microorganism, which should be initiated first by nitrification [3].

$$
\mathrm{NO}_{3}^{-} \rightarrow \quad \mathrm{NO}_{2}^{-} \rightarrow \quad \mathrm{NO} \rightarrow \quad \mathrm{N}_{2} \mathrm{O} \rightarrow \mathrm{N}_{2}
$$

Denitrification is the use of carboneceous organic matter by heterotrophic bacteria to utilize nitrate- nitrogen as the terminal electron acceptor, now being the oxygen source. Many of the heterotrophic bacteria in biological wastewater treatment systems are capable of using either dissolved oxygen or nitrate-nitrogen as terminl electron acceptor [17]. In denitrification process, the electron donor is typically one of three sources: (a) the soluble substrate in the influent wastewater, 
(b) the soluble substrate produced during endogenous decay, and (c) an exogenous source such as methanol or acetate [3]. These three sources are considered as the carbon source for the bacteria. The biodegradable organic matter in wastewater usually is represented as $\mathrm{C}_{10} \mathrm{H}_{19} \mathrm{O}_{3} \mathrm{~N}[18]$.

Wastewater:

$$
\mathrm{C}_{10} \mathrm{H}_{19} \mathrm{O}_{3} \mathrm{~N}+10 \mathrm{NO}_{3}^{-} \rightarrow 5 \mathrm{~N}_{2}+10 \mathrm{CO}_{2}+3 \mathrm{H}_{2} \mathrm{O}+\mathrm{NH}_{3}+10 \mathrm{OH}^{-}
$$

Methanol:

$$
5 \mathrm{CH}_{3} \mathrm{OH}+6 \mathrm{NO}_{3}^{-} \rightarrow 3 \mathrm{~N}_{2}+5 \mathrm{CO}_{2}+7 \mathrm{H}_{2} \mathrm{O}+6 \mathrm{OH}^{-}
$$

Acetate:

$$
5 \mathrm{CH}_{3} \mathrm{COOH}+8 \mathrm{NO}_{3}^{-} \rightarrow 4 \mathrm{~N}_{2}+10 \mathrm{CO}_{2}+6 \mathrm{H}_{2} \mathrm{O}+8 \mathrm{OH}^{-}
$$

Eqn 12 is the overall denitrification reaction considering the synthesis of new cells and assuming a chemical biomass composition [19].

$$
\begin{aligned}
4.53 \mathrm{NO}_{3}{ }^{-}+0.61 \mathrm{C}_{18} \mathrm{H}_{19} \mathrm{O}_{9} \mathrm{~N} & +0.39 \mathrm{NH}_{4}{ }^{+}+4.15 \mathrm{H}_{2} \mathrm{CO}_{3} \rightarrow \mathrm{C}_{5} \mathrm{H}_{7} \mathrm{NO}_{2} \\
+ & 2.27 \mathrm{~N}_{2}+5.15 \mathrm{HCO}_{3}{ }^{-}+5.98 \mathrm{CO}_{2}+14 \mathrm{H}_{2} \mathrm{O}
\end{aligned}
$$

Denitrification produces alkalinity during the reaction. Approximately $3.57 \mathrm{~kg}$ of alkalinity $\left(\mathrm{as}_{\mathrm{CaCO}}\right.$ ) is produced per $\mathrm{kg}$ of nitrate reduced, thus partially mitigating the lowering $\mathrm{pH}$ caused by nitrification in the mixed liquor, almost the half consumed can be recovered [15]. Heterotrophic bacteria need a carbon source as food. Carbon can be obtained from the presence of sufficient soluble organic matter (sCOD), which may be in the form of raw wastewater or supplemental carbon (Metcalf and Eddy [15]). This process is temperature dependent and will best occur between 5 to $30^{\circ} \mathrm{C}$, also rate will increase with temperature and type of organic matter present (Zhao et al. [20]).

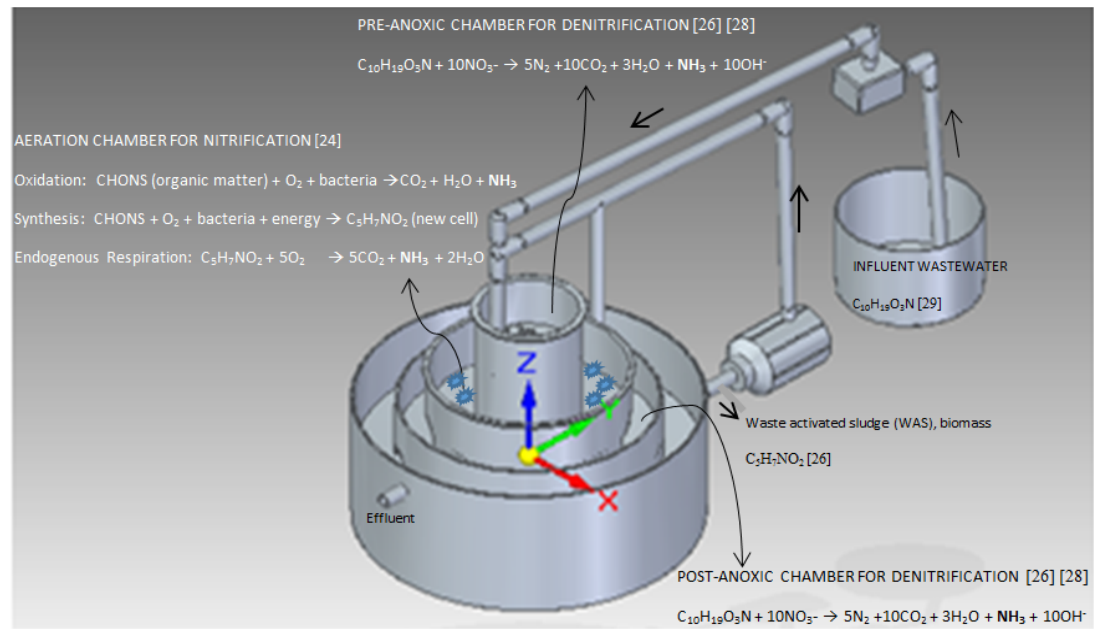

Figure 1: Process for carbon oxidation, nitrification and denitrification in CEAR. 


\section{Materials and method}

\subsection{Experimental set-up}

Concept for configuration of Bardenpho process was used to design CEAR. It was designed to have a volume of 45 litres with units comprising of 2 anoxic chambers, aeration chamber and a clarifier all superimposed within one unit to serve as integrated system for secondary treatment. Circular geometry was considered to fabricate all units within a concentric arrangement, which makes it more compact in handling. Leakages were checked prior to operation and equipment calibrations. Reactor was seeded with 15 liters settled activated sludge taken from sewage treatment plant (STP) of Universiti Teknologi PETRONAS (UTP), and was run on continuous flow with prepared synthetic wastewater. Integrated biological reactor was designed with maximum flow rate capacity of 25 liters/ day and SRT of 40 days. Phase I programme of operation was in 3 stages; Stage A with flow rate of 10 liters/day set for start-up and stability period, maintained between day 1-15 to attain acclimatization, Stage B between day 16-30 with $15 \mathrm{~L} /$ day and Stage $\mathbf{C}$ with $20 \mathrm{~L} /$ day between day $31-45$. Flow variation was done to alter organic loadings as well as hydraulic retention time. The SRT was kept constant and wastage was done in accordance with the eqn 13.

$$
\mathrm{SRT}=(\mathrm{V} . \mathrm{X}) /(\mathrm{Qr} . \mathrm{Xr})=[\text { Solids in system/solids wasting rate }] \text { (days) }
$$

where, SRT is the solids retention time (days), $\mathrm{V}$ is the volume of the reactor (litres), $\mathrm{X}$ and $\mathrm{Xr}$ are the biomass concentrations $(\mathrm{mg} / \mathrm{L})$ in reaction chamber and recycle line, respectively.

Materials used for fabrication of the reactor were made up of uniform $5 \mathrm{~mm}$ thick transparent acrylic tubes, which can resist buckling. The influent container has a mechanical stirrer set to provide complete mixing for the substrate and to avoid stagnation, which if not provided could eventually drop $\mathrm{pH}$ of the wastewater. The influent wastewater is fed by a peristatic pump through flexible tubing. Constant air was supplied by means of centralized air compressor connected to an aquarium round flexible tubing to give fine bubbles from diffusers, with controlled air flow capacity of about 5-6 L/min (LPM), while ensuring dissolved oxygen of $2 \mathrm{mg} / \mathrm{L}$ is maintained in the aeration chamber. The bubbles provide sufficient contact and mixing regime for the bacteria to degrade the organic matter efficiently. The influent is set to directly enter the first anoxic chamber from top, then goes to the aeration chamber, then followed by second anoxic chamber with mixing provided by submerged mixer, and finally wastewater enters clarifier from the bottom drain with slope of $4 \%$. Bottom of the post anoxic to clarifier serves as steeling basin to ensure biomass is not disturbed to increase TSS in effluent. Schematic diagram of experimental set-up for the "CEAR" model is shown in figure 2. The biomass is returned to the anoxic chambers as endogenous carbon source while raw carbon source is set to enter directly into the pre-anoxic chamber. There is also an arrangement for internal recirculation by pumps to return nitrate produced in the aeration chamber to the pre-anoxic chamber for denitrification. 


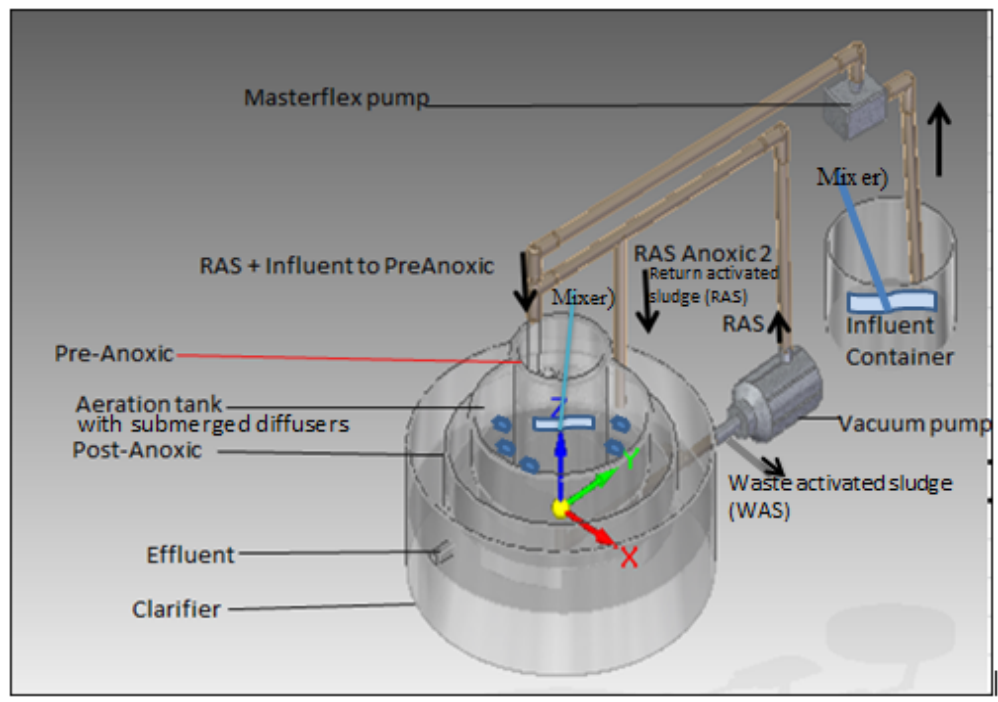

Figure 2: Experimental procedure of CEAR.

\subsection{Method of sampling and performance monitoring}

Samples were taken from five points of the reactor which are influent, pre-anoxic, aeration chamber, post-anoxic and effluent. Samples were also collected from the return sludge line to check for sludge properties due to sludge wastage. A pipette with bulb was used to suck samples at the designated points for performance monitoring. Daily sampling is done during the acclimatization period and every other day onwards.

\subsection{Measurement of sampling parameters}

Analysis of organics, nutrients and sludge for the samples comprised tests on $\mathrm{NH}_{3}$ $\mathrm{N}, \mathrm{NO}_{3}-\mathrm{N}$, Total Kjedhal Nitrogen (TKN), BOD 5 , COD, TSS, Mixed Liquor Suspended Solid (MLSS), Mixed Liquor Volatile Suspended Solids (MLVSS), $\mathrm{pH}$, alkalinity, sludge volume index (SVI) and temperature. Sampling and laboratory analysis were carried out according to Standard methods (APHA and AWWA [21]). Each sample was analysed in triplicate. Samples from each chamber are mixed thoroughly before pipetting. Samples were kept at $4^{\circ} \mathrm{C}$ until they were analysed.

\subsection{Synthetic wastewater Preparation}

Minimum C:N:P ratio of 100:5:1 was reported as to provide an enabling environment for growth of bacteria to degrade organic matter (Kutty et al. [22]). In this research, synthetic water was prepared from particular brand of cat's food to obtain a medium strength wastewater by mixing 1.5 gram and $100 \mathrm{mg} / \mathrm{L}$ ammonium chloride salt to get characteristics in table 1 . 
Table 1: Synthetic wastewater characteristics.

\begin{tabular}{|c|c|c|c|c|c|c|c|c|c|c|}
\hline & \multicolumn{7}{|c|}{ Organic, suspended solids and nutrients $(\mathrm{mg} / \mathrm{L})$} & $\mathrm{mg} / \mathrm{L}$ & & ${ }^{\circ} \mathrm{C}$ \\
\hline & $\mathrm{BOD}_{5}$ & COD & TSS & $\mathrm{NO}_{3}-\mathrm{N}$ & TKN & $\mathrm{NH}_{3}-\mathrm{N}$ & TP & $\begin{array}{l}\text { Alkalinity } \\
\text { as } \mathrm{CaCO}_{3}\end{array}$ & $\mathrm{pH}$ & Temperature \\
\hline \multicolumn{11}{|c|}{ Synthetic wastewater } \\
\hline & 230 & 503 & 453 & 0.3 & 57 & 26 & 10 & 192 & 7 & 28 \\
\hline \multicolumn{11}{|c|}{ Typical medium strength wastewater composition (Metcalf and Eddy, 2003) } \\
\hline & 190 & 430 & 210 & 0 & 40 & 25 & 7 & 140 & & \\
\hline Sludge & \multicolumn{10}{|c|}{ MLSS $=5000 \mathrm{mg} / \mathrm{L}, \quad M L V S S=3400 \mathrm{mg} / \mathrm{L}, \mathrm{SVI}=120 \mathrm{mg} / \mathrm{L}$} \\
\hline
\end{tabular}

\section{Results and discussion}

\subsubsection{Removal of organics (BOD 5 and $C O D$ ) and suspended solids}

$\mathrm{BOD}_{5}$ removal of $92.8 \%$ was achieved in CEAR as average value for the whole phases. The result has complied with both standards A and B of Malaysia's effluent discharge limits of 20 and $50 \mathrm{mg} / \mathrm{L}$, respectively. Average COD removal of $89.5 \%$ was achieved for the study period. All the effluent values obtained were below DOE standard B of $120 \mathrm{mg} / \mathrm{L}$. Stage A had removal efficiency of $86 \%$ with approximate effluent value of $60 \mathrm{mg} / \mathrm{L}$, Stage B had 91\% removal efficiency with effluent value of $46.5 \mathrm{mg} / \mathrm{L}$ and Stage $\mathrm{C}$ had removal efficiency of $91 \%$ with effluent concentration of $42.8 \%$. CEAR has achieved overall removal of TSS at $92.5 \%$ during the study period. Total suspended solids effluent quality slightly declined in last ten days due to increased RAS recirculation, which often agitated the clarifier settled biomass, even though not exceeding the regulatory standards

\subsubsection{Removal of nutrients (ammonia, nitrate and phosphorus)}

Nitrogen removal efficiency of $72 \%$ at $7.3 \mathrm{mg} / \mathrm{L}$ during initial phase of Stage A, Stage B at $97.7 \%$ with value of $5.4 \mathrm{mg} / \mathrm{L}$ effluent concentration and Stage C with $90 \%$ removal efficiency at $2.6 \mathrm{mg} / \mathrm{L}$ in effluent. Average removal efficiency $90 \%$ was obtained. This is likely indication nitrifiers are getting stabilized and multiplying. Average effluent nitrate concentration of $66 \%$ was recorded during the study period. Denitrification has significantly improved during the last phase to achieve effluent nitrate concentration of $80 \%$. Removal of phosphorus was not achieved at optimum level; due to total phosphorus (TP) removal requires an anaerobic medium to achieve desired result. Therefore CEAR will need modification to meet up with the phosphorus removal requirements.

\section{Conclusions}

CEAR is capable of satisfying removal of organics and nutrients to meet the Malaysian department of environment (DOE) new regulations. The compact nature of the reactor has suggested a smaller footprint for effective wastewater treatment alternative. Reactor could perform better when fully stabilized and when microorganisms have adapted. Suitable contact time was ensured to provide sufficient interaction for the biodegradation of substrate and organics. Clarifier is the final sedimentation unit, accumulating all the biomass for recycle. There are larger chunk of biomass concentration compared to anoxic and aeration tanks, with 
average of 8824 and $5981 \mathrm{mg} / \mathrm{L}$ MLSS and MLVSS respectively in the return clarifier. The biomass wasting is provided through the return activated sludge (RAS) line. Endogenous respiration also contributes to low concentration of microorganisms in the system. CEAR is uncomplicated in terms of operation and maintenance and has minimal fouling compared to other reactors with inert mediums.

Table 2: Summary of results for removal of organics, nutrients and TSS in CEAR.

\begin{tabular}{|c|c|c|c|c|c|c|c|c|c|}
\hline & \multicolumn{6}{|c|}{ Concentration $(\mathrm{mg} / \mathrm{L})$} \\
\hline & & & & BOD $_{5}$ & COD & $\mathrm{NH}_{4}-\mathrm{N}$ & $\mathrm{NO}_{3}-\mathrm{N}$ & TP & TSS \\
\hline \multirow{19}{*}{ 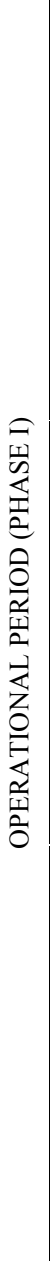 } & \multirow{6}{*}{ 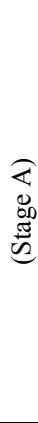 } & & Influent & $\begin{array}{l}189.1 \\
(22.4)\end{array}$ & $\begin{array}{c}446.6 \\
(173.7) \\
\end{array}$ & $\begin{array}{l}26.2 \\
(1.7)\end{array}$ & $\begin{array}{l}0.86 \\
(0.4)\end{array}$ & $\begin{array}{l}12.0 \\
(2.8)\end{array}$ & $\begin{array}{c}512 \\
(35.5) \\
\end{array}$ \\
\hline & & \multirow{3}{*}{ 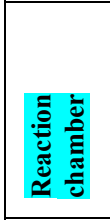 } & Pre-anoxic & $\begin{array}{l}152.1 \\
(31.2)\end{array}$ & $\begin{array}{c}336.2 \\
(154.1)\end{array}$ & $\begin{array}{l}15.5 \\
(1.7)\end{array}$ & $\begin{array}{l}0.74 \\
(0.2)\end{array}$ & $\mathrm{X}$ & X \\
\hline & & & Aeration & $\begin{array}{c}98.5 \\
(32.0)\end{array}$ & $\begin{array}{l}212.4 \\
(80.8)\end{array}$ & $\begin{array}{l}13.3 \\
(1.9)\end{array}$ & $\begin{array}{l}3.15 \\
(0.8)\end{array}$ & $\mathrm{X}$ & $\mathrm{x}$ \\
\hline & & & & $\begin{array}{c}62.8 \\
(18.1)\end{array}$ & $\begin{array}{l}153.3 \\
(80.8)\end{array}$ & $\begin{array}{l}11.2 \\
(2.2)\end{array}$ & $\begin{array}{l}1.93 \\
(0.7)\end{array}$ & $\mathrm{X}$ & $\mathrm{X}$ \\
\hline & & \multicolumn{2}{|r|}{ Effluent } & $\begin{array}{l}23.2 \\
(4.96)\end{array}$ & $\begin{array}{l}59.2 \\
(26.1)\end{array}$ & $\begin{array}{l}7.3 \\
(0.6)\end{array}$ & $\begin{array}{l}1.47 \\
(0.5)\end{array}$ & $\begin{array}{l}10.6 \\
(2.5)\end{array}$ & $\begin{array}{l}39.0 \\
(9.0)\end{array}$ \\
\hline & & \multicolumn{2}{|c|}{$\begin{array}{l}\text { Removal efficiency } \\
(\%)\end{array}$} & $\begin{array}{l}87.8 \\
1.87)\end{array}$ & $\begin{array}{l}86.0 \\
4.01\end{array}$ & $\begin{array}{l}72.2 \\
(2.4)\end{array}$ & $\begin{array}{l}50.7 \\
(19.4)\end{array}$ & 11.7 & $\frac{(9.0)}{92}$ \\
\hline & \multirow{6}{*}{ 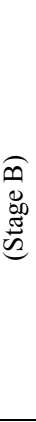 } & & Influent & $\begin{array}{l}186.4 \\
(24.7)\end{array}$ & $\begin{array}{l}505.1 \\
(32.1)\end{array}$ & $\begin{array}{l}28.2 \\
(3.1)\end{array}$ & $\begin{array}{l}0.89 \\
(0.4)\end{array}$ & $\begin{array}{l}14.3 \\
(2.2)\end{array}$ & $\begin{array}{c}493 \\
(39.1)\end{array}$ \\
\hline & & \multirow{3}{*}{ 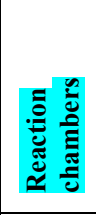 } & Pre-anoxic & $\begin{array}{l}127.3 \\
(13.3)\end{array}$ & $\begin{array}{l}262.2 \\
(43.0)\end{array}$ & $\begin{array}{l}14.2 \\
(3.6)\end{array}$ & $1.1(0.3)$ & $\mathrm{X}$ & $\mathrm{X}$ \\
\hline & & & Aeration & $\begin{array}{c}95.1 \\
(16.9)\end{array}$ & $\begin{array}{l}206.1 \\
(56.5)\end{array}$ & $9.9(3.8)$ & $\begin{array}{l}3.15 \\
(0.9)\end{array}$ & $\mathrm{X}$ & X \\
\hline & & & Post-anoxic & $\begin{array}{c}49.2 \\
(1.99)\end{array}$ & $92.9(26.5)$ & $7.2(2.1)$ & $\begin{array}{l}1.84 \\
(0.2)\end{array}$ & $\mathrm{X}$ & $\mathrm{X}$ \\
\hline & & & Effluent & $\begin{array}{c}16.9 \\
(1.99)\end{array}$ & $46.5(15.9)$ & $5.4(1.9)$ & $\begin{array}{l}0.98 \\
(0.2)\end{array}$ & $\begin{array}{l}11.7 \\
(1.6)\end{array}$ & $\begin{array}{c}27.9 \\
(14.4)\end{array}$ \\
\hline & & \multicolumn{2}{|c|}{$\begin{array}{l}\text { Removal efficiency } \\
(\%)\end{array}$} & $90.9(1.36)$ & $1.0(16.0)$ & .08) & $\begin{array}{l}6.5 \\
12.5)\end{array}$ & $18.0(3)$ & $4.3(2$. \\
\hline & \multirow{7}{*}{$\begin{array}{l}0 \\
0 \\
0 \\
0 \\
0 \\
0\end{array}$} & & Influent & $\begin{array}{l}243.2 \\
(10.5)\end{array}$ & $\begin{array}{l}492.0 \\
(18.4)\end{array}$ & $\begin{array}{l}27.1 \\
(2.4)\end{array}$ & $\begin{array}{l}0.94 \\
(0.4)\end{array}$ & $\begin{array}{l}13.6 \\
(2.3)\end{array}$ & $\begin{array}{c}471 \\
(38.8)\end{array}$ \\
\hline & & & Pre-anoxic & $\begin{array}{l}143.2 \\
(17.2)\end{array}$ & $\begin{array}{l}255.2 \\
(34.6)\end{array}$ & $\begin{array}{l}11.9 \\
(1.0)\end{array}$ & $\begin{array}{l}1.06 \\
0.28)\end{array}$ & $\mathrm{X}$ & $\mathrm{x}$ \\
\hline & &. & Aeration & 92.4 & 200.5 & $84(20)$ & $\begin{array}{l}3.79 \\
(08)\end{array}$ & $x$ & $\mathrm{X}$ \\
\hline & & ๕ँ స్ & & & 117.8 & & 1.54 & & \\
\hline & & & Post-anoxic & $42.2 \quad(14.0)$ & (36.9) & $4.9(0.8)$ & $(0.39)$ & $\mathrm{X}$ & $\mathrm{X}$ \\
\hline & & & Effluent & $\begin{array}{l}17.5 \\
(3.23)\end{array}$ & $42.8(7.9)$ & $2.6(0.3)$ & $\begin{array}{c}0.78 \\
(0.21)\end{array}$ & $\begin{array}{l}10.4 \\
(1.6)\end{array}$ & $\begin{array}{c}43 \\
(7.0)\end{array}$ \\
\hline & & Remova & 1 efficiency & & & & & 23.0 & $1(1.6$ \\
\hline & & $\begin{array}{l}\text { Overall } \\
(\%)\end{array}$ & $\begin{array}{l}\text { efficiency } \\
\text { Mean } \\
\text { Std. Dev } \\
\end{array}$ & $\begin{array}{c}\text { BOD }_{5} \\
\quad 92.8 \\
(1.20)\end{array}$ & $\begin{array}{c}\text { COD } \\
\frac{89.5}{(3.60)}\end{array}$ & $\begin{array}{r}\mathrm{NH}_{4}-\mathrm{N} \\
\mathbf{8 1 . 1} \\
\mathbf{( 8 . 5 0 )}\end{array}$ & $\begin{array}{c}\mathrm{NO}_{3}-\mathrm{N} \\
\frac{66}{(17.8)}\end{array}$ & $\begin{array}{c}\text { TP } \\
23 \\
(10.4)\end{array}$ & $\begin{array}{l}\text { TSS } \\
\frac{92.5}{(2.63)}\end{array}$ \\
\hline
\end{tabular}

Values in brackets are standard deviation (Std. Dev.). 


\section{Acknowledgements}

Authors wish to gracefully recognize the research funding body, prototype development research grant scheme (PRGS) for the financial support. We remain grateful to the management of the Universiti Teknologi PETRONAS (UTP) for the rare opportunity of being privileged to carry out a research of such capacity.

\section{References}

[1] DOE, "Environmental Quality (Sewage) Regulations 2009, Environmental Quality Act 1974, Environmental Quality (Control of Pollution from Solid Waste Transfer Station and Landfill) Regulations 2009,” D. O. E. Malaysia, ed: 2009.

[2] S. Kutty, M. Isa, and L. Leong, "The Effect of Ammonia Loading on the Nitrification Kinetic of Aerobic Baffled Continuous Biological Reactor," International Journal of Environmental Science and Development, vol. 2, pp. 259-263, 2011.

[3] R. W. Howarth, G. Billen, D. Swaney, A. Townsend, N. Jaworski, K. Lajtha, et al., "Regional nitrogen budgets and riverine N \& P fluxes for the drainages to the North Atlantic Ocean: Natural and human influences," in Nitrogen cycling in the North Atlantic Ocean and its watersheds, ed: Springer, 1996, pp. 75-139.

[4] R. I. Sedlak, Phosphorus and nitrogen removal from municipal wastewater: principles and practice: CRC Press, 1991.

[5] S. Hait and D. Mazumder, "High-rate wastewater treatment by a shaft-type activated sludge reactor," Int J Civil Env Eng, vol. 3, pp. 22-27, 2011.

[6] S. Kutty, M. Isa, and L. Leong, "Removal of Ammonia-Nitrogen (NH3-N) and Nitrate by Modified Conventional Activated-Sludge System to Meet New DOE Regulations," 2011.

[7] J. S. Baron, N. L. Poff, P. L. Angermeier, C. N. Dahm, P. H. Gleick, N. G. Hairston Jr, et al., Meeting ecological and societal needs for freshwater, vol. 12, 2002.

[8] Z. Ujang and M. Henze, Municipal wastewater management in developing countries: Principles and engineering: IWA Publishing, 2006.

[9] S. S. Department (SSD), "Guidelines for Developers. Volume 4: Sewage Treatment Plants, 2nd Edition. Malaysia: Ministry of Housing and Local Government.," ed: 1999.

[10] A. Chiplunkar and K. Seetharam, "in Urban Water Management," 2012.

[11] Y. Salama, M. Chennaoui, M. Mountadar, M. Rihani, and O. Assobhei, "Influence of support media on COD and BOD removal from domestic wastewater using biological treatment in batch mode," Desalination and Water Treatment, pp. 1-7, 2014.

[12] P.-S. Keng, S.-L. Lee, S.-T. Ha, Y.-T. Hung, and S.-T. Ong, "Cheap materials to clean heavy metal polluted waters," in Green Materials for Energy, Products and Depollution, ed: Springer, 2013, pp. 335-414.

[13] G. T. Daigger, H.C. Lim, Wastewater Treatment vol. 63, 2011. 
[14] S. P. Carroll, "Risk-based approach to on-site wastewater treatment system siting design and management," Queensland University of Technology, 2005.

[15] Metcalf and Eddy, Wastewater Engineering, Treatment and Reuse: Mc Graw Hill, 2004.

[16] C. Grunditz and G. Dalhammar, "Development of nitrification inhibition assays using pure cultures of nitrosomonas and nitrobacter," Water Research, vol. 35, pp. 433-440, 2001.

[17] R. Christian, Wastewater Treatment: Concepts and Design Approach: PHI Learning Pvt. Ltd., 2006.

[18] G. Bitton, Wastewater microbiology: John Wiley \& Sons, 2005.

[19] S. R. Hoover and N. Porges, "Assimilation of dairy wastes by activated sludge: II. The equation of synthesis and rate of oxygen utilization," Sewage and Industrial Wastes, pp. 306-312, 1952.

[20] L. Zhao, T. Chai, and Q. Cong, "Hybrid dynamic model of anoxic-aeration biological wastewater treatment plant," in Intelligent Control and Automation, 2006. WCICA 2006. The Sixth World Congress on, 2006, pp. 4781-4785.

[21] APHA and AWWA, "Standard Methods for the Examination of Water and Wastewater. 19th ed., Washington, DC: American Public Health Association/America Water Works Association,” ed: 1995.

[22] S. R. M. Kutty, S. G. Khaw, C. L. Lai, and M. H. Isa, "Removal of Copper Using Microwave Incinerated Rice Husk Ash (MIRHA) in Continuous Flow Activated Sludge System," presented at the International Conference on Civil, Offshore \& Environmental Engineering (ICCOEE2012), 2012. 